This article was downloaded by: [University of Auckland Library]

On: 23 March 2014, At: 13:13

Publisher: Routledge

Informa Ltd Registered in England and Wales Registered Number: 1072954 Registered office: Mortimer House, 37-41 Mortimer Street, London W1T 3J H, UK

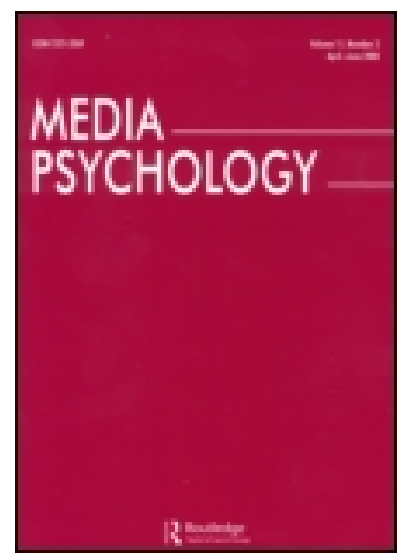

\title{
Media Psychology
}

Publication details, including instructions for authors and subscription information:

http:// www. tandfonline.com/loi/ hmep20

\section{Self-Perceived Effects of Pornography Consumption in a Sample of Indonesian University Students}

\author{
Teguh Wij aya Mulya ${ }^{a} \&$ Gert Martin Hald ${ }^{b c}$ \\ ${ }^{a}$ Faculty of Psychology, University of Surabaya, Surabaya, Indonesia \\ ${ }^{b}$ Department of Public Health, University of Copenhagen, \\ Copenhagen, Denmark \\ c Sexological Clinic, Psychiatric Centre Copenhagen, University \\ Hospital of Copenhagen, Copenhagen, Denmark \\ Published online: 18 Feb 2014.
}

To cite this article: Teguh Wijaya Mulya \& Gert Martin Hald (2014) Self-Perceived Effects of Pornography Consumption in a Sample of Indonesian University Students, Media Psychology, 17: 1, 78-101, DOI: $10.1080 / 15213269.2013 .850038$

To link to this article: http:// dx. doi.org/ 10.1080/ 15213269.2013.850038

\section{PLEASE SCROLL DOWN FOR ARTICLE}

Taylor \& Francis makes every effort to ensure the accuracy of all the information (the "Content") contained in the publications on our platform. However, Taylor \& Francis, our agents, and our licensors make no representations or warranties whatsoever as to the accuracy, completeness, or suitability for any purpose of the Content. Any opinions and views expressed in this publication are the opinions and views of the authors, and are not the views of or endorsed by Taylor \& Francis. The accuracy of the Content should not be relied upon and should be independently verified with primary sources of information. Taylor and Francis shall not be liable for any losses, actions, claims, proceedings, demands, costs, expenses, damages, and other liabilities whatsoever or howsoever caused arising directly or indirectly in connection with, in relation to or arising out of the use of the Content.

This article may be used for research, teaching, and private study purposes. Any substantial or systematic reproduction, redistribution, reselling, loan, sub-licensing, systematic supply, or distribution in any form to anyone is expressly forbidden. Terms \& Conditions of access and use can be found at http://www.tandfonline.com/page/termsand-conditions 


\title{
Self-Perceived Effects of Pornography Consumption in a Sample of Indonesian University Students
}

\author{
TEGUH WIJAYA MULYA \\ Faculty of Psychology, University of Surabaya, Surabaya, Indonesia \\ GERT MARTIN HALD \\ Department of Public Health, University of Copenhagen, Copenhagen, Denmark; \\ Sexological Clinic, Psychiatric Centre Copenhagen, University Hospital of Copenhagen, \\ Copenhagen, Denmark
}

\begin{abstract}
Self-perceived effects of pornography consumption were studied in a sample of university students in Indonesia- a conservative, Muslim majority country with strict anti-pornography laws. Using a cross-sectional design and a modified version of the Pornography Consumption Effect Scale (PCES), we assessed participants' reports of how pornography affected their sexual knowledge, attitude toward sex, sex life, perception of and attitude toward the opposite gender, and life in general. The area of attitude toward sex excepted, the study found that both men and women reported significantly larger positive than negative effects. Further, as compared to women, men reported significantly larger negative effects of their pornography consumption. For both genders, pornography-related variables were found to add significantly to the prediction of both positive and negative self-perceived effects of pornography consumption over and above a number of included control variables.
\end{abstract}

Relative to adverse effects, potential positive effects of pornography consumption remain greatly understudied (Diamond, 2009; Doring, 2009; McKee, 2007a, 2007b). Further, effects of pornography consumption have been studied almost exclusively using Western background samples and without direct reference to the consumers' own self-perceived experiences of such

The findings and conclusions in this article are those of the authors and do not necessarily represent the views of the University of Surabaya.

Address correspondence to Teguh Wijaya Mulya, Faculty of Psychology, University of Surabaya, Jl. Raya Kalirungkut, Surabaya 60293, Indonesia. E-mail: teguh@ubaya.ac.id 
effects (e.g., Hald, Smolenski, \& Rosser, 2013; Weinberg, Williams, Kleiner, \& Irizarry, 2010).

While such studies remain crucial to the study of effects of pornography at large, more direct approaches to the study of effect and culturally diverse study samples would allow for cross-cultural comparison and additional insights into effects of pornography consumption.

In the following, we use a culturally unique university sample of young adults from Indonesia, a religious, sexually conservative Muslim-majority nation with strict anti-pornography laws. Using this sample and relying on self-reports, we study consumers' beliefs about how their experiences with pornography may have affected them in areas related to sexual knowledge, the sex life and behaviors, attitudes toward sex, attitudes toward and perception of the opposite gender, and quality of life in general. Accordingly, we first provide a short oversight of sexuality in Indonesia. We then explicate the theoretical framework of our study. Last, we review relevant empirical literature on pornography and conclude with our study hypotheses.

Indonesia is the world's most populous Muslim-majority nation with roughly 240 million inhabitants (Bureau of Statistics, 2010). From a Western point of view, sexuality in Indonesia may be considered highly conservative and sex is socially acceptable only within monogamous, heterosexual, religiously recognized marriages (Blackwood, 2007; Nilan, 2008; Utomo, 1997). Production, distribution, and consumption of pornography are prohibited by law and violation of the pornography laws carries sentences between 6 months and 12 years of imprisonment (The President of the Republic of Indonesia, 2008). However, the enforcement of the anti-pornography laws remains weak and consequently they are not (yet) rigorously enforced (see also Assegaf, 2002).

Recent changes in socioeconomic conditions, modernization, and access to global media among Indonesian youth have encouraged greater freedom and autonomy during the past two decades, contributing to the more liberal expression of sexual identity and sexual attitudes and behaviors (Harding, 2008; Utomo, 1997; Utomo \& McDonald, 2009). Accordingly, recent research utilizing Indonesian samples indicates that both attitudinal and behavioral sexual permissiveness, including premarital sexual activities, is rising (Bennett, 2007; Ichwanny, 2010; Simon \& Paxton, 2004) and that pornography is widely consumed (e.g., Hald \& Wijaya Mulya, 2013; Supriati \& Fikawati, 2009). While the high rates of pornography consumption in Indonesia have been discussed elsewhere (Hald \& Wijaya Mulya, 2013), no prior research has targeted the self-perceived and self-reported effects of such consumption. We position investigations into this as important as they may enrich the scientific and public debate on pornography consumption in Indonesia and elsewhere by bringing a consumer perspective to the debate (Blackwood, 2007; Hald, Seaman, \& Linz, 2013). Further, such research using diverse samples allow for cross-cultural com- 
parison with existing comparable research (e.g., Boies, 2002; Weinberg et al., 2010).

Theoretically, our research is rooted in sexual script theory (Gagnon \& Simon, 1973). Broadly, sexual script theory proposes that sexual interactions and behaviors are guided by sexual scripts, which themselves are continuously shaped and reshaped by a variety of cultural, historical, social, interpersonal, individual, and intrapsychic processes and experiences (Gagnon \& Simon, 1973; Simon \& Gagnon, 1986). Sexual scripts may be understood as "culturally available messages that define what 'counts' as sex, how to recognize sexual situations, and what to do in a sexual encounter" (Frith \& Kitzinger, 2001, p. 210). Simon and Gagnon (1986) compare sexual scripts to those used by actors. Accordingly, sexual scripts may serve as a guide and a manual for behaviors in sexual interactions (Hald, Seaman, et al., 2013). Repeated exposure to pornography may influence the scripting process, the sexual scripts, or the evaluation of sexual relations (Hald, Malamuth, \& Lange, 2013). The explicit imagery, underlying messages, symbolic normative nature, and order of sexual behaviors as portrayed in pornography may influence the perceptive, affective, cognitive, and behavioral aspects of sexuality (Štulhofer, Buško, \& Landripet, 2010). Accordingly, pornography through culturally mediated messages and social learning processes may write itself into the sexual scripts influencing perceptions of sexuality (e.g., what sex is), sexual situations (e.g., when is a situation sexual), sexual behaviors (e.g., what to do when having sex), and evaluations of sexual relations (e.g., what constitutes good sex; Escoffier, 2007; Hald, Malamuth, et al., 2013). Thus, for the current study, sexual script theory was used as a theoretical basis for hypothesizing first-person self-report effects of pornography consumption (study hypotheses explicated below). Further hypothesizing regarding the valence attributed to these effects as well as gender differences in the reporting of these effects was determined by the relevant available empirical literature in the area of pornography research as reviewed below.

Traditionally, opponents of pornography have claimed that it may have damaging effects on attitudes and behaviors and hold pornography responsible for a variety of adverse effects including interference with romantic relationships (Albright, 2008; Manning, 2006), sexually aggressive behaviors (Ybarra, Mitchell, Hamburger, Diener-West, \& Leaf, 2011) disrupting marriages, negatively changing men's perceptions of women and women's perceptions of themselves, and sexual addiction (e.g., Manning, 2010; Paul, 2005). To the contrary, proponents of pornography have claimed that little or no such effects of pornography consumption are evident. Rather, they argue that pornography may benefit the individual by increasing sexual satisfaction (Štulhofer et al., 2010) and empowerment (Weinberg et al., 2010), enhancing the sex life, contributing to knowledge about sex, providing a recreational sexual outlet, a buffer against sexual assaults, or helping to treat common sexological dysfunctions (e.g., Britton, Maguire, \& Nathanson, 
1993; Diamond, 2009; Diamond, Jozifkova, \& Weiss, 2011; Kontula, 2008; Wylie \& Pacey, 2011). More recent research on pornography has highlighted that pornography may not influence everyone in the same way (Malamuth, Hald, \& Koss, 2012) but that effects of pornography on sexual outcomes are moderated and mediated by various individual and contextual differences (Hald, Kuyper, Adam, \& De Wit, 2013; Hald, Malamuth, et al., 2013).

Most available research on pornography does not include a first-person perspective (Hald, Smolenski, et al., 2013). Accordingly, only a few quantitative studies have been conducted on self-perceived and self-reported effects of customers' pornography consumption experiences (e.g., Boies, 2002; Hald \& Malamuth, 2008; Hald, Smolenski, et al., 2013; Sørensen \& Kjørholt, 2007).

These few studies have all used Western background samples and found that consumers, especially male consumers, self-perceive more positive than negative effects from such consumption in areas related to sexual arousal, curiosity, and the learning of new sexual techniques (Boies, 2002; Hald, Smolenski, et al., 2013), sexual knowledge, the sex life, attitudes toward sex, attitudes toward and perception of the opposite gender, and quality of life in general (Hald \& Malamuth, 2008), the appeal and practice of a variety of sexual acts and sexual empowerment (Weinberg et al., 2010), and the mimicking of sexual behaviors from pornography to the sex life (Sørensen \& Kjørholt, 2007). Also, generally, these and comparable studies demonstrate that men generally report significantly larger self-perceived effects of their pornography consumption than women, such as in relation to sexual arousal (Chivers, Seto, Lalumiere, Laan, \& Grimbos, 2010; Sørensen \& Kjorholt, 2007; Træen, Spitznogle, \& Beverfjord, 2004).

Relatively unexplored in previous studies on self-reported and selfperceived effects of pornography consumption are investigations of which variables may best predict such effects. Thus, previous studies in the area have either not investigated predictors of self-perceived effects or have included only a limited number of potentially relevant predictors (e.g., Weinberg et al., 2010). Accordingly, an important goal of the current study was to more comprehensively assess and explore predictors of self-perceived effects of pornography consumption.

Various previous research on pornography has consistently demonstrated that pornography-related variables predict levels of pornography consumption (see also Hald, 2006; Sinković, Štulhofer, \& Božić, 2013). Therefore, we find it plausible that pornography-related variables such as age of first exposure, acceptance of pornography, perceived realism of pornography, and pornography consumption will significantly predict self-reported and self-perceived effects of pornography consumption in this study. Nonetheless, more recent research in the area of pornography and sexual behaviors also suggests that when controlling for a number of individual, cultural, and contextual covariates, the contribution of pornography-related variables to the outcome variable studied may be substantially reduced (Hald, Kuyper, 
et al., 2013; Peter \& Valkenburg, 2011; Sinković et al., 2013; Wright, 2013; Wright \& Randall, 2012). Consequently, as this reduced contribution may also apply to self-reported and self-perceived effects of pornography consumption, we find it important to assess the contribution of pornography-related variables to self-perceived effects of pornography consumption only after the inclusion of other relevant non-pornography-related study variables.

In this study, these variables were selected on the basis of their frequency by which they have been included in previous research on pornography or because previously they have been shown to be significantly associated with self-reported and self-perceived effects of pornography consumption. On this basis we included sociodemographic predictors (i.e., gender, age, relationship status, religiosity; Morgan, 2011; Peter \& Valkenburg, 2011; Træen, Nilsen, \& Stigum, 2006), personality characteristics (i.e., sensation seeking; Hald, Kuyper, et al., 2013; Luder et al., 2011; Peter \& Valkenburg, 2011; Sinković et al., 2013), sexual background predictors (i.e., sexual attitudes and sexual behaviors; Hald, Kuyper, et al., 2013; Luder et al., 2011), parental involvement (Sinković et al., 2013), and Internet use (Morgan, 2011).

Based on the above, we hypothesized that:

H1: Men and women will report significantly larger positive than negative effects of their pornography consumption.

H2: Men will report significantly more positive and negative effects of their pornography consumption than women.

H3: Pornography-related variables (i.e., age of first exposure, acceptance of pornography, pornography perceived realism, and pornography consumption) will significantly predict self-reported and self-perceived effects of pornography consumption over and above included nonpornography-related variables.

\section{METHOD}

\section{Participants}

The main study sample included 556 Indonesian university students. However, for this part of the study, specifically aimed at self-perceived effects of pornography consumption, only participants reporting to have used pornography within the past 12 months were included.

Accordingly, for this study participants included 249 Indonesian university students aged 18-23 years from a private university in Surabaya, the second-largest city of Indonesia. Students at the university come from Surabaya, surrounding towns, and other islands in Indonesia. Ethnically, students at the university are diverse, including Javanese, Balinese, Madurese, Chinese, and Banjarese participants. Major religions of the students included 
Islam, Christianity, and Buddhism. The majority of students came from middle-class backgrounds. Among participants, $112(44.8 \%)$ were male and $137(54.8 \%)$ female. The mean age was 20.4 years $(S D=1.28)$ for male and 20.1 years $(S D=1.28)$ for female participants. For details of participants' social-demographic characteristics, see Table 1.

\section{Procedure}

The study was approved by the relevant authorities at the university in which the research took place. Data was collected throughout June 2011. Four research assistants, three females and one male, randomly approached potential participants on the campus area. Following a short oral and written explanation of the study, consenting participants were first asked to complete a formal form of consent before filling out the study questionnaires. The response rate was $96.2 \%$. To ensure participants' anonymity, consent forms were removed from the unmarked study questionnaires, which upon completion, were dropped in a separate closed box. Participants were alone during the questionnaire response phase. Participants were also instructed to leave items blank if they felt uncomfortable answering instead of responding dishonestly.

\section{Measures}

BACKGROUND VARIABLES

Sociodemographic variables. Sociodemographic characteristics included gender, age (in years), relationship status $(0=$ not in a relationship; $1=$ in a relationship), and religious attendance (i.e., hours per week spent at religious activities both individual and communal; see also Rohrbaugh \& Jessor, 1975).

Sensation seeking. Sensation seeking was measured using the 8-item Brief Sensation Seeking Scale developed by Stephenson, Velez, Chalela, Ramirez, and Hoyle (2007). Responses were given on a 4-point scale $(1=$ strongly disagree; $2=$ disagree; $3=$ agree; $4=$ strongly agree). A sensation seeking score was computed by summing scores on each item. Higher scores indicate higher sensation seeking. Internal consistency of the scale was satisfactory $(\alpha=.74)$.

Sexual attitude toward nonmarital sexual activities (sexual attitude). Sexual attitude was assessed using five items measuring participants' attitude toward certain nonmarital sexual activities. Responses ranged from 1 (bighly unacceptable) to 4 (bighly acceptable). The five items included dry kissing (mouth-to-mouth kisses without involving saliva), deep kissing (mouthto-mouth kiss involving saliva), petting (manual stimulation of erogenous zones), oral sex (oral-genital stimulation), and coitus (sex involving penetration with the penis; Herbenick et al., 2010). Higher scores indicate a more 
TABLE 1 Background Measures Stratified by Gender $\left(N_{\text {total }}=249\right)$

\begin{tabular}{|c|c|c|c|c|c|}
\hline Variable & Men \% & Women \% & Tests & $d f$ & $\begin{array}{l}\text { Cohen's } \\
\text { (d) }\end{array}$ \\
\hline Gender & $44.8(112)$ & $54.8(137)$ & & & \\
\hline Age & & & $\chi^{2}=1.22$ & 2 & .14 \\
\hline $18-19$ & $28.8(30)$ & $35.6(47)$ & & & \\
\hline $20-21$ & $53.8(56)$ & $49.2(65)$ & & & \\
\hline $22-23$ & $17.3(18)$ & $15.2(20)$ & & & \\
\hline Relationship status & & & $\chi^{2}=3.73$ & 1 & .25 \\
\hline Not in a relationship & $58.7(64)$ & $46.3(62)$ & & & \\
\hline In a relationship & $41.3(45)$ & $53.7(72)$ & & & \\
\hline $\begin{array}{c}\text { Average hours of religious } \\
\text { attendance per week }\end{array}$ & & & $t=.01$ & 226 & .00 \\
\hline$M$ & 6.4 & 6.4 & & & \\
\hline$S D$ & 17.9 & 15.5 & & & \\
\hline$N$ & 103 & 125 & & & \\
\hline Sensation seeking & & & $\chi^{2}=5.77$ & 3 & .31 \\
\hline Very high & $12.6(14)$ & $11.7(16)$ & & & \\
\hline High & $53.2(59)$ & $49.6(68)$ & & & \\
\hline Low & $27.9(31)$ & $37.2(51)$ & & & \\
\hline Very low & $6.3 \quad(7)$ & $1.5 \quad(2)$ & & & \\
\hline $\begin{array}{l}\text { Average hours of Internet } \\
\text { use per week }\end{array}$ & & & $\chi^{2}=13.09^{*}$ & 4 & .48 \\
\hline $0-10$ & $57.8(63)$ & $63.7(86)$ & & & \\
\hline $11-20$ & $14.7(16)$ & $17.0(23)$ & & & \\
\hline $21-30$ & $9.2(10)$ & 14.1 (19) & & & \\
\hline $31-40$ & $4.6 \quad(5)$ & $3.0 \quad(4)$ & & & \\
\hline More than 40 & $13.8(15)$ & $2.2 \quad(3)$ & & & \\
\hline Parental involvement & & & $\chi^{2}=.52$ & 3 & .09 \\
\hline Very high & $24.3(27)$ & $26.3(36)$ & & & \\
\hline High & $60.4(67)$ & $56.2(77)$ & & & \\
\hline Low & $14.4(16)$ & $16.8(23)$ & & & \\
\hline Very low & $0.9 \quad(1)$ & $0.7 \quad(1)$ & & & \\
\hline $\begin{array}{l}\text { Sexual attitude toward } \\
\text { nonmarital sexual } \\
\text { activities }\end{array}$ & & & $\chi^{2}=7.54$ & 3 & .35 \\
\hline Strongly positive & 8.1 (9) & $5.1 \quad(7)$ & & & \\
\hline Positive & 26.1 (29) & 13.9 (19) & & & \\
\hline Negative & $48.6(54)$ & $59.9(82)$ & & & \\
\hline Strongly negative & 17.1 (19) & $21.2(29)$ & & & \\
\hline Sexual behavior & & & $\chi^{2}=23.62^{* *}$ & 5 & .65 \\
\hline Engaged in 5 activities & $11.8(13)$ & $5.1 \quad(7)$ & & & \\
\hline Engaged in 4 activities & $2.7 \quad(3)$ & $8.1(11)$ & & & \\
\hline Engaged in 3 activities & $12.7(14)$ & $9.6(13)$ & & & \\
\hline Engaged in 2 activities & $17.3(19)$ & $40.4(55)$ & & & \\
\hline Engaged in 1 activity & $11.8(13)$ & $11.0(15)$ & & & \\
\hline Never & $43.6(48)$ & $25.7(35)$ & & & \\
\hline
\end{tabular}

Note. Missing values excluded. Numbers in parentheses represent $\mathrm{n} /$ cell.

$* p<.05$.

$* * 0.01$. 
positive attitude toward nonmarital sexual activities. The internal consistency of the scale was good $(\alpha=.85)$.

Sexual behaviors in nonmarital relationships. Sexual behaviors were measured using five items indicating whether participants had engaged in certain nonmarital sexual activities. These included dry kissing (mouth-tomouth kiss without involving saliva), deep kissing (mouth-to-mouth kiss involving saliva), petting (manual stimulation of erogenous zones), oral sex (oral-genital stimulation), and coitus (penetration with the penis; Herbenick et al., 2010). Responses were given in a yes or no manner $(0=$ no/never engaged in the activity, $1=$ yes/have engaged in the activity). A sexual behavior score was computed by summing scores on each item. Higher scores indicate having engaged in more nonmarital sexual behaviors.

Internet consumption. Internet consumption was assessed by a selfreported item measuring the average number of hours of Internet use per week during the previous 12 months.

Parental involvement. Parental involvement was measured by six items taken from Lam and Chan (2007). Parental involvement refers to the degree of "participation of parents/guardians in the children's life and their dedication in trying to help solve their children's problems" (Lam \& Chan, 2007, p. 592). A sample item was "My parents/guardians find time to talk with me." Responses ranged from 1 (strongly disagree) to 4 (strongly agree). Higher scores indicate higher parental involvement in the participant's life. The internal consistency of the scale was satisfactory $(\alpha=.76)$.

PORNOGRAPHY CONSUMPTION AND RELATED VARIABLES

Pornography consumption. Pornography consumption and associated variables were assessed using a modified version of the Pornography Consumption Questionnaire (PCQ) developed by Hald (2006). To standardize the meaning of the term pornography, initially a definition of pornography identical to that used by Hald (2006) and Hald and Malamuth (2008) was provided as follows: Any kind of material aiming at creating or enhancing sexual feelings or thoughts in the recipient and, at the same time (1) containing explicit exposure and/or descriptions of the genitals and (2) clear and explicit sexual acts such as vaginal intercourse, anal intercourse, oral sex, masturbation, bondage, sadomasochism (SM), rape, urine sex, animal sex, and so on. Participants were told to refer to this definition whenever the term was used throughout the questionnaire.

The modified version of the PCQ consisted of 27 items, shortened from the original 139-item instrument. We selected items after considering their relevance and comprehensibility for the Indonesian context. Questions were related to prevalence rates of pornography consumption, age of first exposure, the situational and interpersonal context of pornography consumption, pornography consumption outlets, sexual activity accompanying pornography consumption, perceived realism of pornographic content, acceptance 
of pornography, and partner knowledge of and reactions to participant's pornography consumption (Carroll et al., 2008; Hald, 2006; Štulhofer, Buško, \& Schmidt, 2012). In addition, as specified below, items assessing a variety of self-perceived effects of pornography consumption were included. For details of participants' pornography-related measures, see Table 2.

To yield a better overall estimate of pornography consumption, several indicators of pornography consumption (time since last consumption, frequency of consumption, duration of consumption, and sexual activity accompanying consumption) were collapsed into a pornography consumption composite measure, using the average standardized score of the indicators. This was done to avoid multicollinearity, as variables were highly correlated, and to decrease the risk of inflating the total explained variance of pornography consumption on self-perceived effects in the regression analyses following below (see also Hald, 2006). Higher scores indicate higher levels of pornography consumption. The internal consistency of the scale was $\operatorname{good}(\alpha=.80)$

\section{OUTCOME VARIABLES}

Self-perceived effects of pornography consumption. Self-perceived effects of pornography consumption were measured using a modified version of the 47-item Pornography Consumption Effect Scale (PCES) originally developed by Hald and Malamuth (2008) and later modified by Hald, Smolenski, et al. (2013). In the current study, 14 of the 47 original items were used (i.e., items 1, 4, 5, 10, 12, 26, 29, 30, 31, 33, 36, 40, 41, 45 of the original scale; see also Hald \& Malamuth, 2008). The 14 items were putatively organized into two categories, namely a Positive Effect Dimension (PED) (i.e., items $1,5,6,7,9,10,11,12,14)$ and a Negative Effect Dimension (NED) (i.e., items 2, 3, 4, 8, 13; see also Appendix). For each item, participants were asked to indicate the extent to which they believed that their consumption of pornography had affected them in relation to their: sexual knowledge (SK), attitudes toward sex (ATS), sexual behavior or sex life (SL), perception of and attitude toward the opposite gender (PATOG), and life in general (LG). Responses ranged from 1 (not at all) to 4 (to a very large extent). As in Hald and Malamuth (2008), items were subjected to psychometric validation (more below).

\section{RESULTS}

\section{Missing Data}

Because of the delicate nature of the topic, gender stratified missing value analyses were conducted for all included variables. Except for variables related to hours of religious attendance per week, average duration of pornog- 
TABLE 2 Pornography-Related Measures Stratified by Gender $\left(N_{\text {total }}=249\right)$

\begin{tabular}{|c|c|c|c|c|c|}
\hline Variable & Men $\%$ & Women \% & Tests & $d f$ & $\begin{array}{l}\text { Cohen's } \\
\text { (d) }\end{array}$ \\
\hline Age of first exposure & & & $\chi^{2}=39.35^{* *}$ & 3 & 0.87 \\
\hline $5-8$ years & 1.8 (2) & 2.2 (3) & & & \\
\hline $9-12$ years & $20.0(22)$ & $9.5(13)$ & & & \\
\hline $13-16$ years & $52.7(58)$ & $23.4(32)$ & & & \\
\hline More than 16 years & $25.5(28)$ & $65.0(89)$ & & & \\
\hline Acceptance of pornography & & & $\chi^{2}=7.62$ & 3 & 0.36 \\
\hline Highly acceptable & $17.1(19)$ & $12.5 \quad(17)$ & & & \\
\hline Acceptable & $63.1(70)$ & $77.9(106)$ & & & \\
\hline Unacceptable & $13.5(15)$ & $7.4 \quad(10)$ & & & \\
\hline Highly unacceptable & $6.3(7)$ & $2.2 \quad(3)$ & & & \\
\hline Perceived realism of pornography & & & $t=-1.40$ & 245 & -0.18 \\
\hline$M$ & 4.5 & 4.9 & & & \\
\hline$S D$ & 2.1 & 2.0 & & & \\
\hline$N$ & 112 & 135 & & & \\
\hline Time since last consumption & & & $\chi^{2}=61.70^{* *}$ & 5 & 1.15 \\
\hline In the last 24 hours & $7.1 \quad(8)$ & $2.9 \quad(4)$ & & & \\
\hline In the last 48 hours & $8.9(10)$ & $2.2(3)$ & & & \\
\hline In the last week & $38.4(43)$ & $7.4(10)$ & & & \\
\hline In the last month & $24.1(27)$ & $22.1(30)$ & & & \\
\hline In the last 6 months & $11.6(13)$ & $30.9(42)$ & & & \\
\hline In the last year & $9.8(11)$ & $34.6(47)$ & & & \\
\hline $\begin{array}{l}\text { Frequency of consumption in the } \\
\text { last } 6 \text { months }\end{array}$ & & & $\chi^{2}=72.80^{* * *}$ & 5 & 1.30 \\
\hline More than 5 times per week & 7.2 (8) & $0.7 \quad(1)$ & & & \\
\hline $3-5$ times per week & 8.1 (9) & $1.5 \quad(2)$ & & & \\
\hline 1-2 times per week & $34.2(38)$ & $4.4 \quad(6)$ & & & \\
\hline $1-2$ times per month & $20.7(23)$ & $13.3(18)$ & & & \\
\hline Less than once per month & $19.8(22)$ & $45.2(61)$ & & & \\
\hline Never in the last 6 months & $9.9(11)$ & $34.8(47)$ & & & \\
\hline $\begin{array}{l}\text { Duration of consumption (hours per } \\
\text { week in the last } 6 \text { months) }\end{array}$ & & & $\chi^{2}=38.08^{* * *}$ & 5 & 0.85 \\
\hline Never in the last 6 months & $10.4(11)$ & $40.2(47)$ & & & \\
\hline Less than 1 hour & $29.2(31)$ & $29.8(35)$ & & & \\
\hline $1-3$ hours & $53.8(57)$ & $28.2(33)$ & & & \\
\hline 4-6 hours & $3.8 \quad(4)$ & $0.9 \quad(1)$ & & & \\
\hline $7-10$ hours & $0.9 \quad(1)$ & $0.9 \quad(1)$ & & & \\
\hline More than 10 hours & $1.9 \quad(2)$ & $0.0 \quad(0)$ & & & \\
\hline $\begin{array}{l}\text { Composite measure of pornography } \\
\text { consumption }\end{array}$ & & & $t=9.30^{* *}$ & 201.2 & 1.31 \\
\hline$M$ & 0.9 & 0.01 & & & \\
\hline$S D$ & 0.8 & 0.6 & & & \\
\hline$N$ & 112 & 137 & & & \\
\hline Type of pornography consumed & & & $\chi^{2}=4.31$ & 5 & 0.29 \\
\hline Vaginal sex & $65.0(65)$ & $60.3(70)$ & & & \\
\hline Oral sex & $10.0(10)$ & $19.0(22)$ & & & \\
\hline Group sex & $8.0 \quad(8)$ & 7.8 (9) & & & \\
\hline Containing violence & $5.0 \quad(5)$ & $4.3 \quad(5)$ & & & \\
\hline Children/teenager & $2.0 \quad(2)$ & $2.6 \quad(3)$ & & & \\
\hline Others (e.g., cartoon, blonde, etc.) & $10.0(10)$ & $6.0 \quad(7)$ & & & \\
\hline $\begin{array}{l}\text { Sexual activity accompanying } \\
\text { pornography consumption }\end{array}$ & & & $\chi^{2}=88.65^{* *}$ & 3 & 1.50 \\
\hline Always & $2.7 \quad(3)$ & 2.2 & & & \\
\hline Often & $18.8(21)$ & $1.5 \quad(2)$ & & & \\
\hline Sometimes & $58.0(65)$ & $17.0 \quad(23)$ & & & \\
\hline Never & $20.5(23)$ & $79.3(107)$ & & & \\
\hline
\end{tabular}

Note. Missing values excluded. Numbers in parentheses represent $\mathrm{n} /$ cell.

${ }^{*} p<.05$.

$* * p<.01$. 
raphy consumption, and type of pornography consumed, missing values ranged from 0 to $5 \%$ with the vast majority of missing values being below $2 \%$. For the three items noted above, missing values ranged from 8 to 13\%. No systematic differences between respondents and nonrespondents across missing values were found (see also Howell, 2007). Considering this, missing values were excluded pairwise in the subsequent analyses.

\section{Factor Analyses}

Factor analysis was employed to investigate if items in the modified version of the PCES also, statistically, could be meaningfully organized into the two categories specified above. For the final factor solution, a principal axis factoring with varimax rotation was employed to maximize item loadings, and because the factors, using oblimin factor rotation, were found only to be modestly ( $r=.16$ ), albeit significantly, correlated.

Both the scree plot and the Kaiser-Guttmann rule suggested that two common factors should be extracted. Thus, items a priori organized within the positive and negative effect dimensions were found to have their salient loadings on separate factors, that is, factor 1 and 2, respectively, with factor loadings greater than .40 . The total explained variance of the two extracted factors was 45.04\%. Accordingly, as in Hald and Malamuth (2008), factor analysis was found to support the theoretical notion of two separate effect dimensions each comprised of the items specified above and each measuring various aspects of self-reported effects of pornography consumption. Further, intercorrelations between items and the overall effects dimension were found to be high, ranging from .52 to .81 for the positive effect dimension, and .57 to .88 for the negative effect dimension.

\section{Reliability Analyses}

The reliability of the two effect dimensions were investigated using Cronbach's alpha. For both effect dimensions, the internal consistency was found to be satisfactory. Cronbach's alpha for the positive effect dimension was .80, while for the negative effect dimension Cronbach's alpha was .73.

\section{Hypotheses Testing}

H1: Men and women will report significantly larger positive than negative effects of their pornography consumption.

As shown in Table 3, with two exceptions noted below, paired sample $t$ tests showed that both genders were found to report significantly larger positive than negative effects of pornography consumption in the areas investigated, with the magnitude of these differences being large (Cohen's $d$ 
TABLE 3 Comparison of Mean Differences in Positive and Negative Effects of Pornography Consumption by Gender $\left(N_{\text {men }}=112, N_{\text {women }}=137\right)$

\begin{tabular}{|c|c|c|c|c|c|c|}
\hline \multirow[b]{2}{*}{ Variables } & \multicolumn{3}{|c|}{ MDPositive-Negative } & \multicolumn{2}{|c|}{$\begin{array}{c}t \text { Test for } \\
\text { paired samples }\end{array}$} & \multirow{2}{*}{$\begin{array}{l}\text { Effect size } \\
\text { Cohen's } d\end{array}$} \\
\hline & $M$ & $S D$ & $N$ & $t$ & $d f$ & \\
\hline \multicolumn{7}{|l|}{ Men } \\
\hline Sex life & 0.62 & 0.95 & 112 & $6.85^{* *}$ & 111 & 1.30 \\
\hline Attitudes toward sex & -0.48 & 1.13 & 112 & $-4.50^{* * *}$ & 111 & -0.85 \\
\hline Perception and attitudes & 0.63 & 1.27 & 112 & $5.30^{* * *}$ & 111 & 1.01 \\
\hline Life in general & 0.07 & 1.17 & 112 & 0.67 & 111 & 0.13 \\
\hline Overall & 0.32 & 0.83 & 112 & $4.10^{* * *}$ & 111 & 0.78 \\
\hline \multicolumn{7}{|l|}{ Women } \\
\hline Sex life & 0.70 & 0.83 & 137 & $9.88^{* *}$ & 136 & 1.69 \\
\hline Attitudes toward sex & -0.34 & 0.95 & 137 & $-4.16^{* * *}$ & 136 & -0.71 \\
\hline Perception and attitudes & 0.50 & 1.01 & 137 & $5.81^{* * *}$ & 136 & 1.00 \\
\hline Life in general & 0.42 & 0.87 & 137 & $5.60^{* * *}$ & 136 & 0.96 \\
\hline Overall & 0.45 & 0.61 & 137 & $8.69^{* *}$ & 136 & 1.49 \\
\hline
\end{tabular}

${ }^{*} p<.05$.

$* * 0.01$.

range: .78 to 1.69). The two exceptions concerned the areas of attitudes toward sex and life in general. For attitudes toward sex, both genders reported significantly larger negative effects of their pornography consumption with the magnitude of these differences being large. For life in general, women reported significantly larger positive than negative effects whereas for men no significant differences were found.

H2: Men will report significantly more positive and negative effects of their pornography consumption than women.

For positive effects, with one exception, the independent sample $t$ tests showed that no gender differences were found $(p>.05)$. The exception concerned the area of the perception and attitude toward opposite gender, where men reported significantly larger positive effects of their pornography consumption than women. For negative effects, with one exception, men reported significantly larger negative effects of their pornography consumption than women. The exception concerned the area of the sex life, where no significant gender differences were evident (see also Table 4).

H3: Pornography-related variables (i.e., age of first exposure, acceptance of pornography, pornography perceived realism, and pornography consumption) will significantly predict self-reported and self-perceived effects of pornography consumption over and above included nonpornography-related variables. 
TABLE 4 Gender Differences in Self-Perceived Effects of Pornography Consumption $\left(N_{\text {men }}=\right.$ $\left.112, N_{\text {women }}=137\right)$

\begin{tabular}{|c|c|c|c|c|c|c|c|}
\hline \multirow[b]{2}{*}{ Variables } & \multicolumn{2}{|c|}{ Men } & \multicolumn{2}{|c|}{ Women } & \multicolumn{2}{|c|}{$\begin{array}{c}t \text { Test for } \\
\text { independent } \\
\text { samples }\end{array}$} & \multirow{2}{*}{$\begin{array}{l}\text { Effect size } \\
\text { Cohen's } d\end{array}$} \\
\hline & $M$ & $S D$ & $M$ & $S D$ & $t$ & $d f$ & \\
\hline \multicolumn{8}{|l|}{ Positive effect on } \\
\hline Sex life & 2.57 & 0.63 & 2.56 & 0.61 & 0.16 & 247 & 0.02 \\
\hline Attitudes toward sex & 2.03 & 0.70 & 1.89 & 0.64 & 1.59 & 247 & 0.20 \\
\hline Sexual knowledge & 2.87 & 0.52 & 2.75 & 0.47 & 1.86 & 247 & 0.24 \\
\hline Perception and attitudes & 2.89 & 0.80 & 2.56 & 0.72 & $3.48^{* *}$ & 247 & 0.44 \\
\hline Life in general & 2.30 & 0.83 & 2.34 & 0.72 & -0.49 & 247 & -0.06 \\
\hline Overall positive effect & 2.56 & 0.47 & 2.45 & 0.41 & 1.88 & 247 & 0.24 \\
\hline \multicolumn{8}{|l|}{ Negative effect on } \\
\hline Sex life & 1.96 & 0.66 & 1.85 & 0.56 & 1.31 & 247 & 0.17 \\
\hline Attitudes toward sex & 2.51 & 0.75 & 2.23 & 0.67 & $3.07^{* *}$ & 226.28 & 0.41 \\
\hline Perception and attitudes & 2.26 & 0.88 & 2.06 & 0.64 & $2.01^{*}$ & 197.76 & 0.29 \\
\hline Life in general & 2.22 & 0.68 & 1.93 & 0.55 & $3.72 * *$ & 213.55 & 0.51 \\
\hline Overall negative effect & 2.23 & 0.54 & 2.00 & 0.46 & $3.68^{* *}$ & 218.15 & 0.50 \\
\hline
\end{tabular}

Note. Missing data excluded pairwise.

*p $<<.05$.

$* * 0.01$.

For our investigation of predictors of self-reported and self-perceived effects of pornography consumption, both correlational analyses and hierarchical multiple regression analyses were employed. Analyses were conducted separately for self-perceived positive and negative effects of pornography consumption.

First, correlational analyses were employed to check for multicollinearity among variables and to assess which variables correlated significantly with self-perceived positive and negative effects of pornography consumption respectively. The variables that correlated significantly with self-perceived positive and negative effects of pornography consumption, respectively, were entered into two regression analyses for each of the self-reported effects of pornography using the procedures recommended by Cohen, Cohen, West, and Aiken (2003) and by Aiken and West (1991).

In the first step of the two regression analyses, non-pornography-related study predictors were entered. Subsequently, in the second step of the regression analyses, pornography-related variables significantly correlated with the dependent variable were entered. In both steps of the regression analyses, variables were force entered into the regression model using an $F$ probability criteria of .05 for inclusion and .10 for removal.

As evident in Tables 5 and 6 for self-perceived positive effects of pornography consumption, the first step included relationship status, sensation seeking, sexual attitude, sexual behavior, and parental involvement. For the 


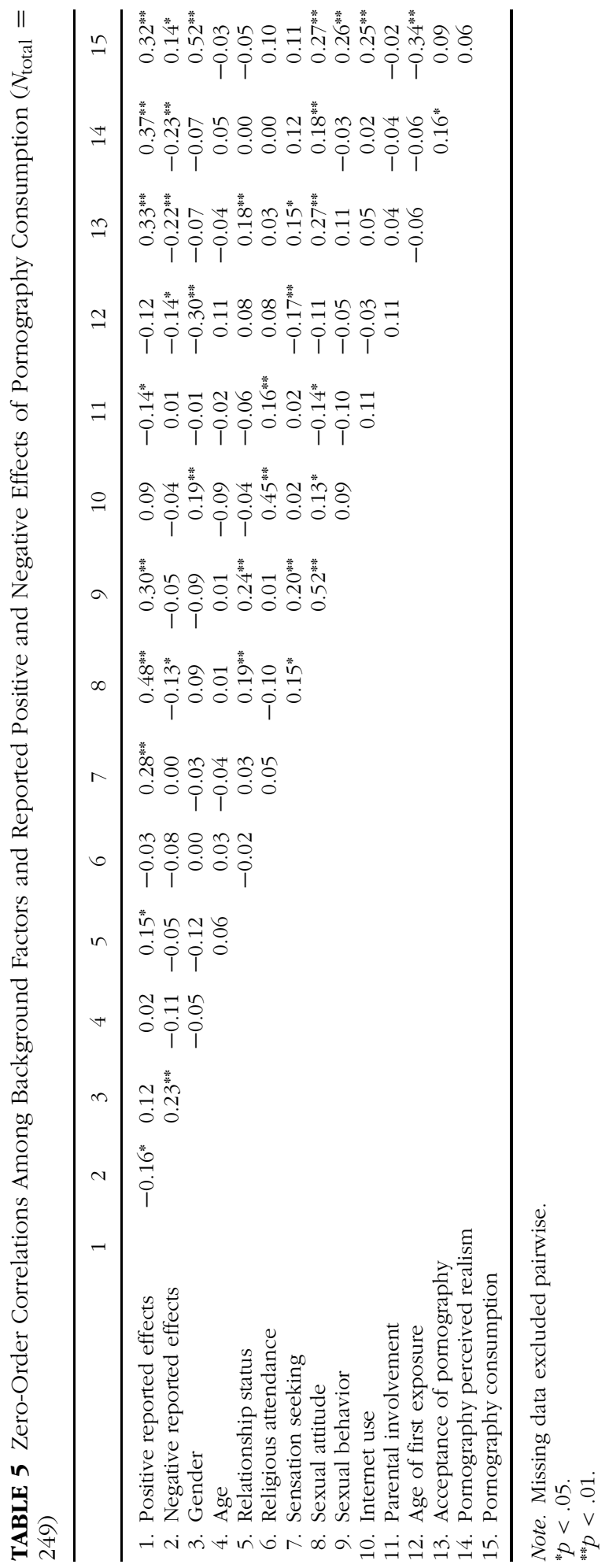


TABLE 6 Hierarchical Regression Analyses Predicting Positive and Negative Effects of Pornography Consumption $\left(N_{\text {total }}=249\right)$

\begin{tabular}{|c|c|c|c|}
\hline & $\Delta R^{2}$ & $\mathrm{~B}$ & $t$ \\
\hline \multicolumn{4}{|l|}{ Positive effects of consumption } \\
\hline Step 1 & $0.27^{* *}$ & & \\
\hline Relationship status & & 0.058 & 1.121 \\
\hline Sensation seeking & & 0.152 & $2.973^{* *}$ \\
\hline Sexual attitude toward nonmarital sexual activities & & 0.258 & $4.171^{* *}$ \\
\hline Sexual behavior & & 0.053 & 0.875 \\
\hline Parental involvement & & -0.090 & -1.803 \\
\hline Step 2 & $0.13^{* *}$ & & \\
\hline Acceptance of pornography & & 0.169 & $3.211^{* *}$ \\
\hline Perceived realism of pornography & & 0.267 & $5.207^{* *}$ \\
\hline Pornography consumption & & 0.185 & $3.542 * *$ \\
\hline Total $R^{2}$ adjusted & $0.40^{* *}$ & & \\
\hline \multicolumn{4}{|l|}{ Negative effects of consumption } \\
\hline Step 1 & $0.07^{* *}$ & & \\
\hline Gender & & 0.136 & 1.900 \\
\hline Sexual attitude toward nonmarital sexual activities & & -0.093 & -1.445 \\
\hline Step 2 & $0.06^{* *}$ & & \\
\hline Age of first exposure & & -0.101 & -1.579 \\
\hline Acceptance of pornography & & -0.167 & $-2.686^{* *}$ \\
\hline Perceived realism of pornography & & -0.193 & $-3.157^{* *}$ \\
\hline Pornography consumption & & 0.082 & 1.111 \\
\hline Total $R^{2}$ adjusted & $0.13^{* *}$ & & \\
\hline
\end{tabular}

Note. Missing data excluded pairwise.

$* p<.05$.

$* * 0<.01$.

second step, it included acceptance of pornography, perceived realism of pornography, and pornography consumption.

For self-perceived negative effects of pornography consumption the first step included gender and sexual attitude. The second step included age of first exposure, acceptance of pornography, perceived realism of pornography, and pornography consumption.

As shown in Table 6, the final model for the prediction of both selfperceived positive and negative effect of pornography consumption was highly significant; positive effect: $F(8,241)=21.42, p<.001, R_{\text {adj }}^{2}=.40$; negative effect: $F(6,243)=7.08, p<.001, R_{\text {adj }}^{2}=.13$. For self-perceived positive effects of pornography consumption, the total explained variance of included variables was $40 \%\left(R=.65, R_{\mathrm{adj}}^{2}=.40, p<.001\right)$. Here pornography consumption related variables added significantly to the prediction of selfperceived positive effects over and above non-pornography-related variables accounting for an additional 13\% of the total explained variance of selfperceived positive effects of pornography consumption.

For self-perceived negative effect of pornography consumption the total explained variance of included variables was $13 \%\left(R=.39 ; R_{\mathrm{adj}}^{2}=.13\right.$; 
$p<.001)$. Here pornography-consumption-related variables also added significantly to the prediction of self-perceived effects over and above nonpornography-related variables accounting for an additional $6 \%$ of the total explained variance of self-perceived negative effects of pornography consumption.

\section{DISCUSSION}

In agreement with the first study hypothesis, it was found that both men and women generally reported significantly larger positive than negative effects of pornography consumption. Furthermore, in most areas investigated, and in support of the second study hypothesis, as compared to women, men reported significantly larger negative effects of their pornography consumption. However, contrary to the second study hypothesis, men generally did not report significantly more positive effects from their pornography consumption than women. Finally, in agreement with the third hypothesis, pornographyrelated variables were found to add significantly to the prediction of both positive and negative self-perceived effects of pornography consumption over and above included non-pornography-related variables.

The study findings may be interpreted as consistent with (sexual) script theory (see also, Introduction) in that consumers generally report that their consumption of pornography has influenced their sexual attitudes and sex life including their sexual behaviors. Thus, pornography as a form of culturally available messages about sexuality is perceived as influential in constructing a guide or a manual in sexual interaction (see also Wilkerson et al., 2012). Accordingly, this may be taken to imply influences on the attitudinal and behavioral aspects of one or more (sexual) scripts (Hald, Seaman, et al., 2013).

The study findings are consistent with the few previous quantitative studies conducted on self-reported and self-perceived effects of pornography consumption using exclusively Western background samples (e.g., Boies, 2002; Sørensen \& Kjørholt, 2007; Weinberg et al., 2010). Interestingly, as compared to Indonesia, these samples come from relatively liberal and sex educated backgrounds in which pornography is widely available and relatively accepted, such as the United States and Denmark. This indicates that although the Indonesian legal, political, media, and educational systems condemn the use of pornography and greatly emphasize negative over positive effects, these discourses do not seem to automatically internalize to consumers' self-reported perceptions and experiences with such materials.

We believe that this may be attributed to three things. First, it may be attributed to a continuous rise of sexual permissiveness due to changes in socioeconomic conditions, modernization, and access to global media among 
young Indonesians in recent years. This may influence both pornography consumption rates, acceptance of pornography consumption, and the ways in which consumption of pornographic materials is perceived and assessed (Bennett, 2007; Hald \& Wijaya Mulya, 2013; Ichwanny, 2010; Simon \& Paxton, 2004; Supriati \& Fikawati, 2009).

Second, it may be attributed to the concept of biased optimism, whereby people consider themselves less likely to be influenced by negative events than they do others (Weinstein, 1989) or generally consider themselves relatively immune to harmful effects of media (Gunther, 1995).

Third, it may be attributed to a response and attention bias by which participants' arousal to and desire for pornography causes them to emphasize positive effects and minimize negative effects (Hald \& Malamuth, 2008).

However, in this regard it is also important to leave open the possibility that individuals accurately perceive and report the impact of their pornography consumption on the areas studied and that the result therefore should be taken at face value.

Interestingly, based on a comparable study using a Danish study sample, Hald and Malamuth (2008) suggest that the cultural background of participants may influence the valance attributed to self-perceived effects of pornography consumption. Accordingly, Hald and Malamuth suggest that participants from a very liberal cultural background such as Denmark, in which pornography consumption is generally widely accepted, might have a reduced awareness of negative effects and an increased awareness of positive effects. This may bias the reporting of effects of pornography consumption in a more positive direction. Although we concur with the general idea of a cultural influence, our study findings seem to refute this basis contention of Hald and Malamuth (2008), as both the study methodology and results of the present study are fully comparable with that of Hald and Malamuth (2008) but the cultural background of this study sample very different (i.e., much more religious, sexually conservative, and anti-pornography). Consequently, following Simon and Gagnon's (1986) sexual script theory, we suggest that it may not primarily be the cultural background per se, which determines the valance attributed to first hand experiences with pornography consumption but more the personal acceptance of and experiences associated with the pornography consumption such as the degree to which this consumption brings about sexual enjoyment and fulfillment.

In contrast to Hald and Malamuth (2008), no significant gender differences were found in the area of self-perceived first person positive effects of pornography consumption. We are unsure of how to exactly interpret this finding but tentatively propose two explanations. First, it may be that gender in an Indonesian cultural context simply is not related to the positive effects outcomes studied here, and that these are more adequately accounted for by other pornography-related and non-pornography-related variables. Certainly, designs better allowing for gender interactional analyses than the current 
study could be used to source out this possibility. Second, the pornography adverse cultural climate of Indonesia in which pornography consumption is contextualized may affect women more than men. Thus, it may be that women who receive or experience only minimal or modest positive effects from their pornography consumption may stop using pornography more so than comparable men. This would mean that for our data set we might in effect be comparing the proportion of female users who experience the most positive effects from their pornography consumption with a group of male users who varies more in their positive effect experiences. This could diminish or erode gender differences in first person positive effects of pornography consumption and as such account for the study finding pertaining to this specific area of investigation. We encourage future research to further this possibility.

Pornography-related variables were found to significantly predict both self-perceived positive and negative effects of pornography consumption over and above other included non-pornography-related study variables. However, the additional variance explained by pornography-related variables on self-perceived effects was somewhat modest after controlling for included non-pornography-related variables. These findings are consistent with previous recent studies in this area which have also found that the additional explained variance of pornography-related variables on the outcomes investigated has been modest when other relevant non-pornography variables have been controlled for (Hald, Kuyper, et al., 2013; Peter \& Valkenburg, 2011; Sinković et al., 2013; Wright, 2013; Wright \& Randall, 2012). This suggests that self-perceived effects of pornography consumption may be as much, or more, associated with factors other than pornographyrelated variables such as gender, sensation seeking, sexual attitude, and sexual behavior. Alternatively, that pornography-related variables are more indirectly related to the self-perceived effects of pornography consumption studied here, for example through mediation by third variables (see also Hald, Malamuth, et al., 2013). We call for further research to employ study designs and methodology that enable further exploration of these possibilities.

\section{Limitations of the Present Study}

At least five important limitations pertain to this study. First, the study utilizes a sample never before studied in this area of research and is one of only a few studies to date to study self-perceived effects of pornography consumption. Consequently, we lack an adequate body of literature and empirical research in which to situate our findings. Second, the study was cross-sectional which precludes causal inferences. Third, the study used a non-probability type sample. Therefore, the study findings cannot be generalized to the Indonesian population at large. Fourth, the study relies exclusively on self-report 
measures without the possibility of verifying these reports. Further, as the purpose of the study was relatively transparent to participants such reports may be subject to demand characteristics which may (further) bias these self-reports. Fifth, although the outcome measure of self-perceived effects has been used and validated in previous studies (e.g., Hald \& Malamuth, 2008; Hald, Smolenski, et al., 2013), only selected items from this measure were used. This may adversely affect both the reliability and validity of the study findings.

\section{Conclusions}

The current study extends the knowledge of effects of pornography consumption by providing a unique cultural study sample against which existing research on self-perceived effects of pornography consumption may be compared. Moreover, it investigates both positive and negative effects of pornography consumption as it is perceived and reported by the consumers themselves, essentially bringing a consumer perspective to the study of effects of pornography consumption. This adds both to the very limited knowledge of self-reported and self-perceived effects of pornography consumption as well as to the still-understudied area of potential positive effects of pornography consumption. Finally, by including a large array of relevant variables, the study allows for a very thorough assessment of the unique direct contribution of pornography-related variables to the prediction of self-perceived effects of pornography consumption. Both this and the study results in general may help enrich public and scientific debates on pornography and inform public and sexual health personnel and policy makers about effects of pornography consumption as they are perceived and reported by the consumers themselves.

\section{FUNDING}

This research was funded by a grant from the University of Surabaya.

\section{REFERENCES}

Aiken, L. S., \& West, S. G. (1991). Multiple regression: Testing and interpreting interactions. Newbury Park, CA: Sage.

Albright, J. M. (2008). Sex in America online: An exploration of sex, marital status, and sexual identity in internet sex seeking and its impacts. Journal of Sex Research, 45, 175-186. doi:10.1080/00224490801987481 
Assegaf, I. (2002). Legends of the fall: An institutional analysis of Indonesian law enforcement agencies combating corruption. In T. Lindsey \& H. Dick (Eds.), Corruption in Asia: Rethinking the government paradigm (pp. 127-146). Sydney, Australia: The Federation Press.

Bennett, L. R. (2007). Zina and the enigma of sex education for Indonesian Muslim youth. Sex Education, 7, 371-386. doi:10.1080/14681810701635970

Blackwood, E. (2007). Regulation of sexuality in Indonesian discourse: Normative gender, criminal law, and shifting strategies of control. Culture, Health \& Sexuality, 9, 293-307. doi:10.1080/13691050601120589

Boies, S. C. (2002). University students' uses of and reactions to online sexual information and entertainment: Links to online and offline sexual behavior. Canadian Journal of Human Sexuality, 11, 77-89.

Britton, P. O., Maguire, J., \& Nathanson, B. (1993). Feminism and free speech: Pornography. New York, NY: Feminists for Free Expression. Retrieved from http://www.ffeusa.org/html/statements/Pornographybrochure.pdf

Bureau of Statistics. (2010). The number and distribution of population. Retrieved from http://sp2010.bps.go.id/

Carroll, J. S., Padilla-Walker, L. M., Nelson, L. J., Olson, C. D., Barry, C. M., \& Madsen, S. D. (2008). Generation XXX-Pornography acceptance and use among emerging adults. Journal of Adolescent Research, 23, 6-30. doi:10.1177/074355 8407306348

Chivers, M., Seto, M., Lalumiere, M., Laan, E., \& Grimbos, T. (2010). Agreement of self-reported and genital measures of sexual arousal in women and men: A meta-analysis. Archives of Sexual Behavior, 39, 5-56. doi:10.1007/s10508-0099556-9

Cohen, J., Cohen, P., West, S. G., \& Aiken, L. S. (2003). Applied multiple regression/ correlation analysis for the behavioral sciences (3rd ed.). Hillsdale, NJ: Erlbaum.

Diamond, M. (2009). Pornography, public acceptance and sex related crime: A review. International Journal of Law and Psychiatry, 32, 304-314. doi:10.1016/ j.ijlp.2009.06.004

Diamond, M., Jozifkova, E., \& Weiss, P. (2011). Pornography and sex crimes in the Czech republic. Archives of Sexual Behavior, 40, 1037-1043. doi:10.1007/s10508010-9696-y

Doring, N. M. (2009). The internet's impact on sexuality: A critical review of 15 years of research. Computers in Human Behavior, 25, 1089-1101. doi:10.1016/j.chb. 2009.04 .003

Escoffier, J. (2007). Scripting the sex: Fantasy, narrative, and sexual scripts in pornographic films. In M. Kimmel (Ed.), The sexual self: The construction of sexual scripts (pp. 61-80). Nashville, TN: Vanderbilt University Press.

Frith, H., \& Kitzinger, C. (2001). Reformulating sexual script theory: Developing a discursive psychology of sexual negotiation. Theory and Psychology, 11, 209232. doi: $10.1177 / 0959354301112004$

Gagnon, J., \& Simon, W. (1973). Sexual conduct: The social sources of human sexuality. Chicago, IL: Aldine.

Gunther, A. C. (1995). Overrating the X-rating: The third-person perception and support for censorship of pornography. Journal of Communication, 45, 27-38. doi:10.1111/j.1460-2466.1995.tb00712.x 
Hald, G. M. (2006). Gender differences in pornography consumption among young heterosexual Danish adults. Archives of Sexual Behavior, 35, 577-585. doi: 10.1007/s10508-006-9064-0

Hald, G. M., Kuyper, L., Adam, P. C. G., \& De Wit, J. B. F. (2013). Does viewing explain doing? Assessing the association between sexually explicit materials use and sexual behaviours in a large sample of Dutch adolescents and young adults. Journal of Sexual Medicine, 10, 2986-2995. doi:10.1111/jsm.12157

Hald, G. M., \& Malamuth, N. M. (2008). Self-perceived effects of pornography consumption. Archives of Sexual Behavior, 37, 614-625. doi:10.1007/s10508007-9212-1

Hald, G. M., Malamuth, N. M., \& Lange, T. (2013). Pornography and sexist attitudes among heterosexuals. Journal of Communication, 63, 638-660. doi:10.1111/ jcom. 12037

Hald, G. M., Seaman, C., \& Linz, D. (2013). Sexuality and pornography. In D. Tolman, L. Diamond, J. Bauermeister, W. George, J. Pfaus, \& M. Ward (Eds.), APA handbook of sexuality and psychology: Vol. 2. Contextual approaches. Washington, DC: American Psychological Association.

Hald, G. M., Smolenski, D., \& Rosser, B. R. S. (2013). Perceived effects of sexually explicit media among men who have sex with men and psychometric properties of the pornography consumption effects scale (PCES). Journal of Sexual Medicine, 10, 757-767. doi:10.1111/j.1743-6109.2012.02988.x

Hald, G. M., \& Wijaya Mulya, T. (2013). Pornography consumption and non-marital sexual behaviour in a sample of young Indonesian university students. Culture, Health, E Sexuality, 15, 981-996. doi:10.1080/13691058.2013.802013

Harding, C. (2008). The influence of the 'decadent west': Discourses of the mass media on youth sexuality in Indonesia. Intersections: Gender and Sexuality in Asia and the Pacific, 18. Retrieved from http://intersections.anu.edu.au/issue18/ harding.htm

Herbenick, D., Reece, M., Schick, V., Sanders, S. A., Dodge, B., \& Fortenberry, J. D. (2010). Sexual behavior in the United States: Results from a national probability sample of men and women ages 14-94. Journal of Sexual Medicine, 7(Suppl. S5), 255-265. doi:10.1111/j.1743-6109.2010.02012.x

Howell, D. C. (2007). The treatment of missing data. In W. Outhwaite \& S. Turner (Eds.), The SAGE handbook of social science methodology (pp. 208-224). London, UK: Sage.

Ichwanny, Y. P. (2010). Sex education and factors influencing adolescents sexual behavior in Indonesia 2007 (Unpublished master's thesis). Flinders University, Adelaide, Australia.

Kontula, O. (2008). The role of pornography in media and in sex education. Tidsskrift for Norsk Psykologforening, 45, 739-742. Retrieved from http://www.psykolog tidsskriftet.no/index.php?seks_id=51898\&a $=2$

Lam, C. B., \& Chan, D. K. S. (2007). The use of cyberpornography by young men in Hong Kong: Some psychosocial correlates. Archives of Sexual Behavior, 36, 588-598. doi:10.1007/s10508-006-9124-5

Luder, M. T., Pittet, I., Berchtold, A., Akre, C., Michaud, P., \& Suris, J. C. (2011). Associations between online pornography and sexual behavior among adolescents: 
Myth or reality? Archives of Sexual Behavior, 40, 1027-1035. doi:10.1007/s10508010-9714-0

Malamuth, N. M., Hald, G. M., \& Koss, M. (2012). Pornography, individual differences in risk and men's acceptance of violence against women in a representative sample. Sex Roles, 66, 427-439. doi:10.1007/s11199-011-0082-6

Manning, J. C. (2006). The impact of internet pornography on marriage and the family: A review of the research. Sexual Addiction \& Compulsivity, 13, 131165. doi:10.1080/10720160600870711

Manning, J. (2010). Who said pornography was acceptable in the workplace? An investigation into the use of pornography by NHS fertility clinics. 2020 Health.org. Retrieved from http://www.2020health.org/2020health/Publications/Publica tions-2010/porn.html

McKee, A. (2007a). 'Saying you've been at dad's porn book is part of growing up': Youth, pornography and education. Metro Magazine, 155, 118-122. Retrieved from http://eprints.qut.edu.au/14574/1/14574.pdf

McKee, A. (2007b). The positive and negative effects of pornography as attributed by consumers. Australian Journal of Communication, 34, 87-104. Retrieved from http://eprints.qut.edu.au/14575/1/14575.pdf

Morgan, E. M. (2011). Associations between young adults' use of sexually explicit materials and their sexual preferences, behaviors, and satisfaction. Journal of Sex Research, 48, 520-530. doi:10.1080/00224499.2010.543960

Nilan, P. (2008). Youth transitions to urban, middle-class marriage in Indonesia: Faith, family and finances. Journal of Youth Studies, 11, 65-82. doi:10.1080/ 13676260701690402

Paul, P. (2005). Pornified: How pornography is transforming our lives, our relationships, and our families. New York, NY: Times Books.

Peter, J., \& Valkenburg, P. M. (2011). The influence of sexually explicit internet material on sexual risk behavior: A comparison of adolescents and adults. Journal of Health Communication: International Perspectives, 16, 750-765. doi:10.1080/10810730.2011.551996

The President of the Republic of Indonesia. (2008). Undang-Undang Republik Indonesia Nomor 44 Tahun 2008 tentang Pornografi [Law Number 44 on Pornography of the Republic of Indonesia]. Retrieved from www.bpkp.go.id/uu/file download/2/33/151.bpkp

Rohrbaugh, J., \& Jessor, R. (1975). Religiosity in youth: A personal control against deviant behavior. Journal of Personality, 43, 136-155. doi:10.1111/j.1467-6494. 1975.tb00577.x

Simon, S., \& Paxton, S. J. (2004). Sexual risk attitudes and behaviors among young adult Indonesians. Culture, Health, E Sexuality, 6, 393-409. doi:10.1080/13691 050410001680519

Simon, W., \& Gagnon, J. H. (1986). Sexual scripts: Permanence and change. Archives of Sexual Behavior, 15, 97-120. doi:10.1007/BF01542219

Sinković, M., Štulhofer, A., \& Božić, J. (2013). Revisiting the association between pornography use and risky sexual behaviors: The role of early exposure to pornography and sexual sensation seeking. Journal of Sex Research, 50, 633641. doi:10.1080/00224499.2012.681403 
Sørensen, A. D., \& Kjørholt, V. S. (2007). How do Nordic adolescents relate to pornography? A quantitative study. In S. V. Knudsen, L. Löfgren-Mårtenson, \& S.-A. Månsson (Eds.), Generation P? Youth, gender and pornography (pp. 87102). Copenhagen, Denmark: Danish School of Education Press.

Stephenson, M. T., Velez, L. F., Chalela, P., Ramirez, A., \& Hoyle, R. H. (2007). The reliability and validity of the Brief Sensation Seeking Scale (BSSS-8) with young adult Latino workers: Implications for tobacco and alcohol disparity research. Addiction, 102(Suppl. S2), 79-91. doi:10.1111/j.1360-0443.2007.01958.x

Štulhofer, A., Buško, V., \& Landripet, I. (2010). Pornography, sexual socialization, and satisfaction among young men. Archives of Sexual Behavior, 39, 168-178. doi:10.1007/s10508-008-9387-0

Štulhofer, A., Buško, V., \& Schmidt, G. (2012). Adolescent exposure to pornography and relationship intimacy in young adulthood. Psychology \& Sexuality, 3, 95107. doi:10.1080/19419899.2010.537367

Supriati, E., \& Fikawati, S. (2009). Efek paparan pornografi pada remaja SMP negeri kota Pontianak tahun 2008 [Effect of pornography exposure among Pontianak junior high school adolescents in 2008]. Makara Sosial Humaniora, 13(1), 4856. Retrieved from http://repository.ui.ac.id/contents/koleksi/2/41c10d192c40d 07c89002b82b3a6eff78e6f3cec.pdf

Træen, B., Nilsen, T. S., \& Stigum, H. (2006). Use of pornography in traditional media and on the Internet in Norway. Journal of Sex Research, 43, 245-254. doi:10.1080/00224490609552323

Træen, B., Spitznogle, K., \& Beverfjord, A. (2004). Attitudes and use of pornography in the Norwegian population 2002. Journal of Sex Research, 41, 193-200. doi:10.1080/00224490409552227

Utomo, I. D. (1997). Sexual attitudes and behavior of middle-class young people in Jakarta (Unpublished doctoral dissertation). The Australian National University, Canberra, Australia.

Utomo, I. D., \& McDonald, P. (2009). Adolescent reproductive health in Indonesia: Contested values and policy inaction. Studies in Family Planning, 40, 133-146. doi:10.1111/j.1728-4465.2009.00196.x

Weinberg, M. S., Williams, C. J., Kleiner, S., \& Irizarry, Y. (2010). Pornography, normalization, and empowerment. Archives of Sexual Behavior, 39, 1389-1401. doi:10.1007/s10508-009-9592-5

Weinstein, N. D. (1989). Optimistic biases about personal risks. Science, 246, $1232-$ 1233. doi:10.1126/science. 2686031

Wilkerson, J. M., Iantaffi, A., Smolenski, D. J., Brady, S. S., Horvath, K. J., Grey, J. A., \& Rosser, B. R. S. (2012). The SEM Risk Behavior (SRB) model: A new conceptual model of how pornography influences the sexual intentions and HIV risk behavior of MSM. Sexual and Relationship Therapy, 27, 217-230. doi:10.1080/14681994.2012.734605

Wright, P. J. (2013). U.S. males and pornography, 1973-2010: Consumption, predictors, correlates. Journal of Sex Research, 50, 60-71. doi:10.1080/00224499.2011. 628132

Wright, P. J., \& Randall, A. K. (2012). Internet pornography exposure and risky sexual behavior among adult males in the United States. Computers in Human Behavior, 28, 1410-1416. doi:10.1016/j.chb.2012.03.003 
Wylie, K., \& Pacey, A. A. (2011). Using erotica in government-funded health service clinics. Journal of Sexual Medicine, 8, 1261-1265. doi:10.1111/j.1743-6109.2011. 02269.x

Ybarra, M. L., Mitchell, K. J., Hamburger, M., Diener-West, M., \& Leaf, P. J. (2011). Xrated material and perpetration of sexually aggressive behavior among children and adolescents: Is there a link? Aggressive Behavior, 37, 1-18. doi:10.1002/ab. 20367

\section{APPENDIX}

\section{Modified Version of the Pornography Consumption Effect Scale (PCES)}

Below is a series of questions. Please indicate your answer to each question using the numbers $1-4$, where $1=$ not at all and $4=$ to a very large extent. Please write your answer in the box [ ] preceding each question. Please answer all questions.

To what extent do you believe that your consumption of pornography:

\begin{tabular}{rll}
\hline 1 & SK (P) & Has taught you new sexual techniques? \\
2 & ATS (N) & Has had a negative influence on your attitudes toward sex? \\
3 & PATOG (N) & Has adversely affected your views of the opposite gender? \\
4 & LG (N) & Overall, has had a harmful effect on your life? \\
5 & SL (P) & Overall, has improved your sex life? \\
6 & SK (P) & Has improved your knowledge of sex? \\
7 & ATS (P) & Has made you more sexually liberal? \\
8 & LG (N) & Has made you less satisfied with your life? \\
9 & SK (P) & Has given you more insight into your sexual fantasies? \\
10 & ATS (P) & Has had a positive influence on your attitudes toward sex? \\
11 & SL (P) & Has added something positive to your sex life? \\
12 & PATOG (P) & Has made you friendlier toward the opposite gender? \\
13 & SL (N) & Has led to problems in your sex life? \\
14 & LG (P) & Has improved your quality of life? \\
\hline
\end{tabular}

Note. $\mathrm{SL}=$ sex life; $\mathrm{LG}=$ life in general; ATS $=$ attitudes toward sex; PATOG = perception of and attitudes toward the opposite gender; $\mathrm{SK}=$ sexual knowledge. $(\mathrm{P})$ indicates that the item belongs to the positive effect dimension. $(\mathrm{N})$ indicates that the item belongs to the negative effect dimension. 

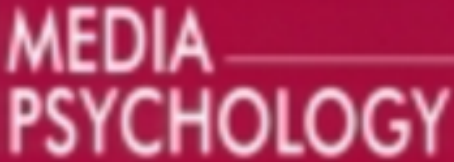
Journal

\title{
Media Psychology >
}

\author{
This journal
}

\section{Journal information}

Print ISSN: 1521-3269 Online ISSN: 1532-785X

4 issues per year

Media Psychology is abstracted/indexed in: Cabell's Directory of Publishing Opportunities in Psychology; ComAbstracts; ComIndex; Communication Abstracts; EBSCOhost Online Research Databases; ERIH - Psychology; Family Index Database; ISI: Social Sciences Citation Index, Social SciSearch, Journal Citation Reports Social Science, Current Contents/Social and Behavioral Sciences, Arts and Humanities Citation Index, Current Contents/Arts \& Humanities; PsycINFO/Psychological Abstracts; and Scopus.

Taylor \& Francis make every effort to ensure the accuracy of all the information (the "Content") contained in our publications. However, Taylor \& Francis, our agents, and our licensors make no representations or warranties whatsoever as to the accuracy, completeness, or suitability for any purpose of the Content. Any opinions and views expressed in this publication are the opinions and views of the authors, and are not the views of or endorsed by Taylor \& Francis. The accuracy of the Content should not be relied upon and should be independently verified with primary sources of information. Taylor \& Francis shall not be liable for any losses, actions, claims, proceedings, demands, costs, expenses, damages, and other liabilities whatsoever or howsoever caused arising directly or indirectly in connection with, in relation to, or arising out of the use of the Content. Terms \& Conditions of access and use can be found at http://www.tandfonline.com/page/terms-and-conditions . 


\section{Media Psychology >}

\section{This journal}

\section{Editorial board}

EDITORS

Francesca R. Dillman Carpentier, Ph.D.

School of Media and Journalism, University of North Carolina at Chapel Hill

Amy Nathanson, Ph.D.

School of Communication, The Ohio State University

Sabine Trepte, Ph.D.

Department of Media Psychology, University of Hohenheim

\section{EDITORIAL ASSISTANT}

Robert Trama - Taylor \& Francis

\section{EDITORIAL BOARD}

Sun Joo (Grace) Ahn - University of Georgia

Markus Appel - University of Koblenz-Landau

Jeremy Bailenson - Stanford University

Anne Bartsch - Ludwig-Maximilian-University Munich

Helena Bilandzic - Augsburg University

Paul Bolls - University of Missouri

Nicholas D. Bowman - West Virginia University

Jennings Bryant - University of Alabama 


\section{I.}

Michael Dalstrom - lowa State University

James P. Dillard - Pennsylvania State University

Travis L. Dixon - University of California at Los Angeles

Steven Eggermont - University of Leuven

David Ewoldsen - The Ohio State University

Melanie C. Green - University of North Carolina at Chapel Hill

Dara N. Greenwood - Vassar College

Al Gunther - University of Wisconsin-Madison

Alice Hall - University of Missouri - St. Louis

Richard Jackson Harris - Kansas State University

Kristen Harrison - University of Michigan

Tilo Hartmann - VU University, Amsterdam

Matthias R. Hastall - TU Dortmund University

Cynthia Hoffner - Georgia State University

James D. Ivory - Virginia Tech

Se-Hoon Jeong - Korea University - Seoul

Benjamin K. Johnson - VU University Amsterdam

Jessie Quintero Johnson - University of Massachusetts - Boston

Christoph Klimmt - Hanover University of Music and Drama

Elly A. Konijn - VU University Amsterdam, Netherlands

Nicole Krämer - University of Duisburg-Essen

Marina Krcmar - Wake Forest University

Ken Lachlan - University of Massachusetts Boston

Annie Lang - Indiana University

Roselyn J. Lee-Won - Ohio State University

Glenn Leshner - University of Oklahoma

Tina M. Lowrey - HEC Paris

Marie-Louise Mares - University of Wisconsin-Madison

Robin Nabi - University of California-Santa Barbara

Mary Beth Oliver - Pennsylvania State University

Jessica Piotrowski - University of Amsterdam

Robert F. Potter - Indiana University

Arthur A. Raney - Florida State University

Niklas Ravaja - University of Helsinki 


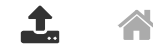

Michael Shapiro - Cornell University

John L. Sherry - Michigan State University

L.J. Shrum - HEC Paris

Michael D. Slater - The Ohio State University

Glenn Sparks - Purdue University

S. Shyam Sundar - Pennsy/vania State University

Ron Tamborini - Michigan State University

David Tewksbury - University of Illinois at Urbana-Champaign

Sabine Trepte - Universität Hohenheim

Yariv Tsfati - University of Haifa

Sonja Utz - Leibniz-Institut für Wissensmedien, Tuebingen

Jan Van den Bulck - University of Leuven, Belgium

Brandon Vanderhiede - Michigan State University

Peter Vorderer - University of Mannheim, Germany

Zheng Joyce Wang - The Ohio State University

Monique Ward - University of Michigan

Kevin Wise - University of Illinois Urbana-Champaign

Changmin Yan - University of Nebraska - Lincoln

FORMER EDITORS

Rick Busselle

Jennings Bryant

David Ewoldsen

Cynthia Hoffner

Annie Lang

Sriram Kalyanaraman

Silvia Knobloch-Westerwick

Elly Konijn

Annie Lang

Eun-Ju Lee

Robin Nabi

Mary Beth Oliver

Michael A. Shapiro

\section{L.J. Shruı}




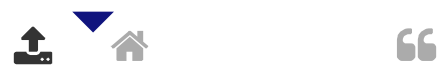

Sign in here

to start your access
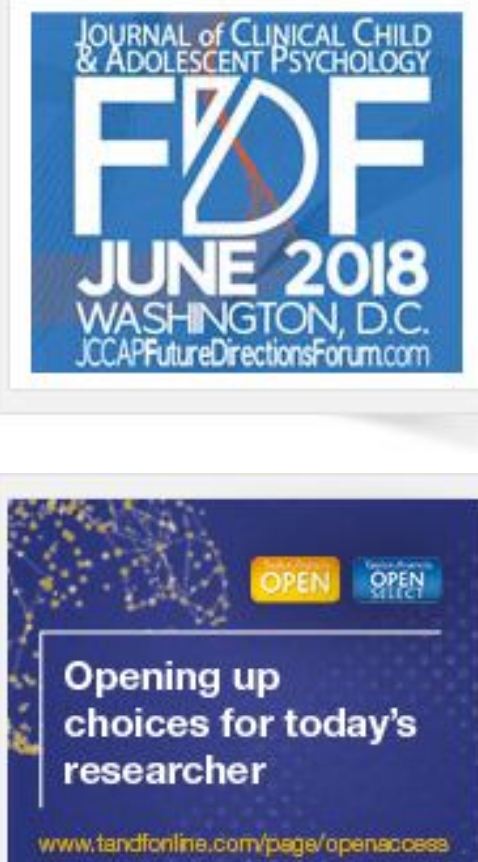


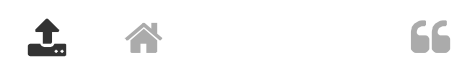

Authors

Editors

Librarians

Societies

Help and info

Help

FAQS

Press releases

Contact us

Commercial services
Overview

Open journals

Open Select

Cogent OA

Connect with Taylor \& Francis

f日in

You

Copyright (C) 2017 Informa UK Limited Privacy policy \& cookies Terms \& conditions Accessibility

Registered in England \& Wales No. 3099067

5 Howick Place | London | SW1P 1WG 


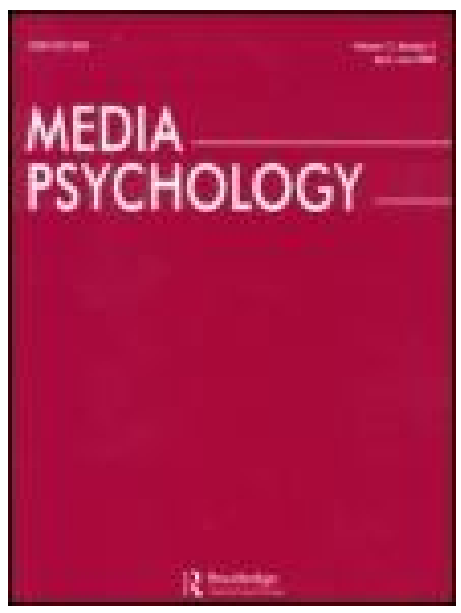

\section{Media Psychology}

\section{Publish open access in this journal}

Submit an article $\square$ New content alerts A RSSÉ Citation search

E Current issue $\equiv$ Browse list of issues

\section{This journal}

Latest two full volumes

FREE to you for 14 days

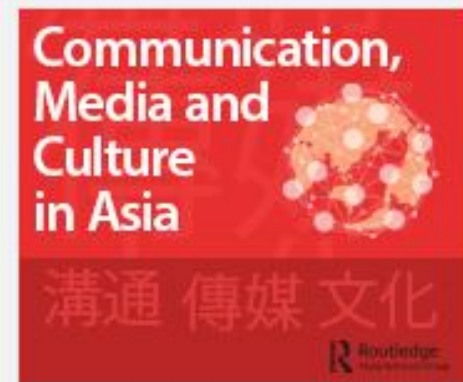




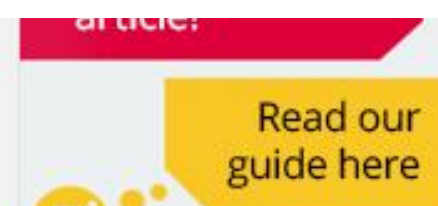

\section{Latest articles}

\begin{tabular}{|c|c|c|c|}
\hline Article & Article & Article & Article \\
\hline Parasocial & Liking the & Pathways to & Mass \\
\hline Relationships & (Funny) & Virality: & Shootings \\
\hline with Media & Messenger: The & Psychophysio & Backfire: The \\
\hline Personae: Why & Influence of & logical & Boomerang \\
\hline They Matter & News Parody & Responses & Effects of \\
\hline Differ Among & $\begin{array}{l}\text { Exposure, } \\
\text { Mirth, and }\end{array}$ & Preceding & Death \\
\hline Heterosexual, & Predispositions & Likes,Shares, & Concerns on \\
\hline Lesbian, Gay, & on Media Trust & Comments, & Policy \\
\hline and Bisexual & $>$ & and Status & Attitudes > \\
\hline Adolescents > & & Updates on & \\
\hline Bond & Peifer & $\begin{array}{l}\text { Facebook > } \\
\text { Alhabash et al. }\end{array}$ & Jang \\
\hline $\begin{array}{l}\text { Published online: } 17 \\
\text { Jan } 2018\end{array}$ & $\begin{array}{l}\text { Published online: } 16 \\
\text { Jan } 2018\end{array}$ & $\begin{array}{l}\text { Published online: } 11 \\
\text { Jan } 2018\end{array}$ & $\begin{array}{l}\text { Published online: } 9 \text { Jan } \\
2018\end{array}$ \\
\hline
\end{tabular}

View more>

See all volumes and issues

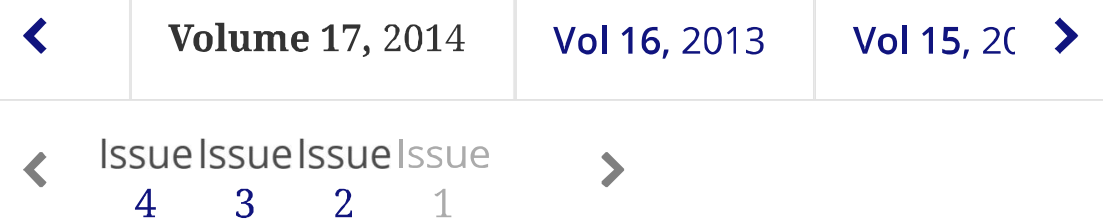

\section{Themed Issue: Sex and the Media}

Editorial

\section{Editorial}


$\underline{\boldsymbol{\Psi}_{\mathrm{s}} \mathrm{Submit}}$ an article

Pages: $1-2$

Published online: 18 Feb 2014

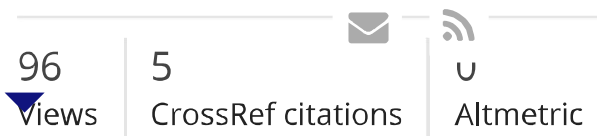

Miscellany

\section{Acknowledgment of Reviewers >}

Pages: 3-5

Published online: 18 Feb 2014

\begin{tabular}{l|l|l}
102 & 0 & 0 \\
Views & CrossRef citations & Altmetric
\end{tabular}

\section{Original Articles}

\section{Article}

Sexting, Mobile Porn Use, and Peer Group Dynamics: Boys' and Girls' Self-Perceived Popularity, Need for Popularity, and Perceived Peer Pressure >

Mariek Vanden Abeele, Scott W. Campbell, Steven Eggermont \& Keith Roe

Pages: 6-33

Published online: 18 Feb 2014

\begin{tabular}{l|l|l|}
\hline 5464 & 23 & 56 \\
Views & CrossRef citations & Altmetric
\end{tabular}

\section{Article}

Revisiting Media Priming Effects of Sexual Depictions: Replication, Extension, and Consideration of Sexual Depiction Strength >

Francesca R. Dillman Carpentier, C. Temple Northup \& M. Scott Parrott

Pages: 34-54

Published online: 18 Feb 2014 


\section{Article}

Impersonal Sex Orientation and Multitasking Influence the Effect of Sexual Media Content on Involvement With a Sexual Character >

Inge Boot, Jochen Peter \& Johanna M. F. van Oosten

Pages: 55-77

Published online: 18 Feb 2014

\begin{tabular}{l|l|l}
417 & 1 & 0 \\
Views & CrossRef citations & Altmetric
\end{tabular}

Article

Self-Perceived Effects of Pornography Consumption in a Sample of Indonesian University Students >

Teguh Wijaya Mulya \& Gert Martin Hald

Pages: 78-101

Published online: 18 Feb 2014

\begin{tabular}{l|l|l}
540 & 7 & 0 \\
Views & CrossRef citations & Altmetric
\end{tabular}

\section{Article}

Sex on the Shore: Wishful Identification and Parasocial Relationships as Mediators in the Relationship Between Jersey Shore Exposure and Emerging Adults' Sexual Attitudes and Behaviors >

Bradley J. Bond \& Kristin L. Drogos

Pages: $102-126$

Published online: 18 Feb 2014

\begin{tabular}{l|l|l}
\hline 1376 & 17 & 3 \\
Views & CrossRef citations & Altmetric
\end{tabular}


Most read articles Most cited articles 6 Open access articles

Article

Social

Cognitive

Theory of

Mass

Communic ation >
Article

Influence of

Mass Media on

Body Image

and Eating

Disordered

Attitudes and

Behaviors in

Females: A

Review of

Effects and

Processes >

López-Guimerà et

al.

Volume 3, 2001 - Issue 3

Published online: 17

Nov 2009

Views: 16686

Volume 13, 2010 - Issue

4
Published online: 15

Dec 2010

Views: 15379
Article

Feeling Better

But Doing

Worse: Effects

of Facebook

Self-

Presentation

on Implicit

Self-Esteem

and Cognitive

Task

Performance >

Toma

Volume 16, 2013 - Issue

Article

Development

and

Validation of

a Game

Addiction

Scale for

Adolescents

$>$

Published online: 30

May 2013

Views: 9607
Lemmens et al.

Volume 12, 2009 - Issue 1

Published online: 5

Mar 2009

Views: 8228

View more> 


\section{SJR Scimago Journal \& Country Rank Enter Journal Title, ISSN or Publisher Name}

Home Journal Rankings Country Rankings Viz Tools Help About Us

\section{Media Psychology}

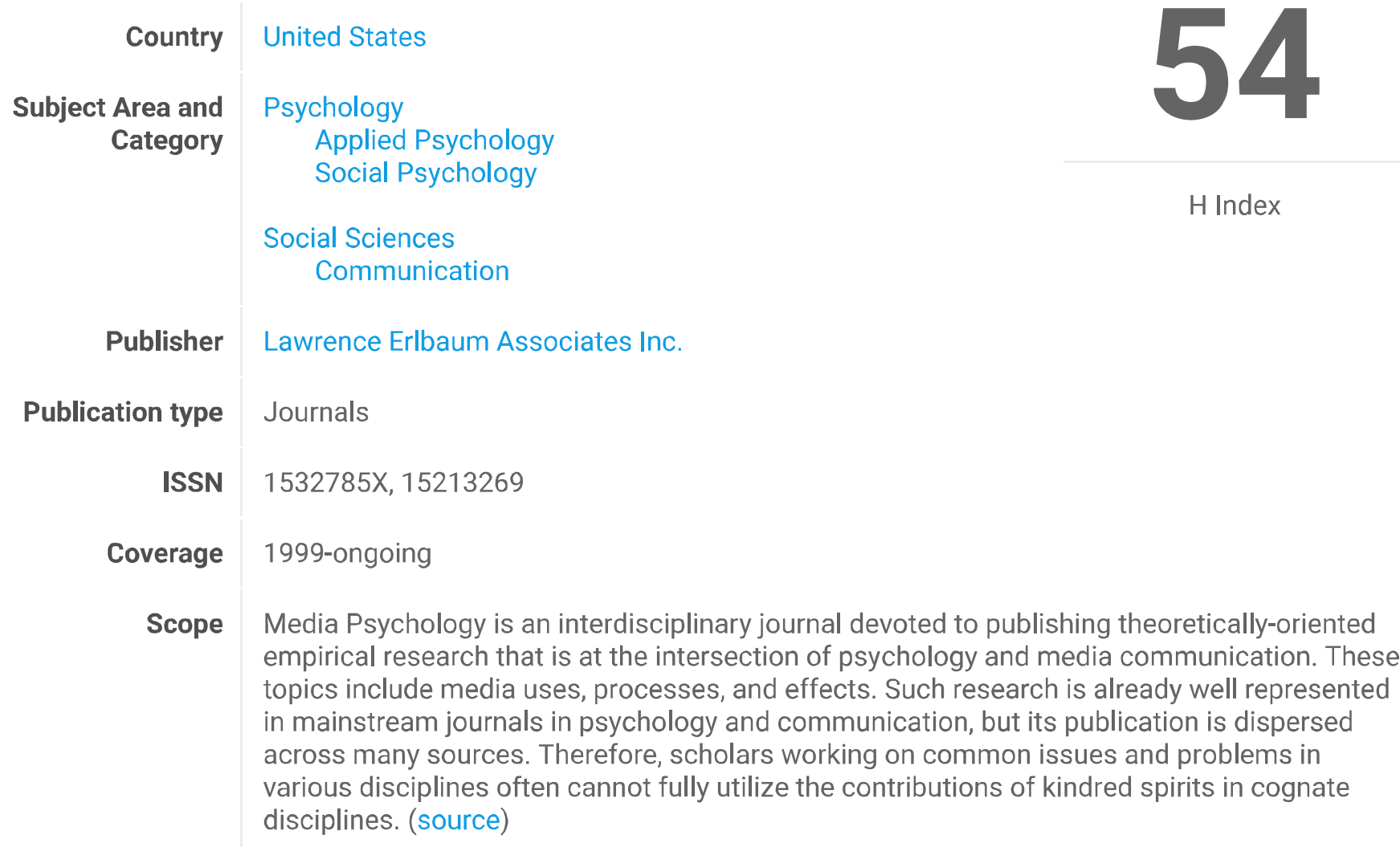

\section{Quartiles}

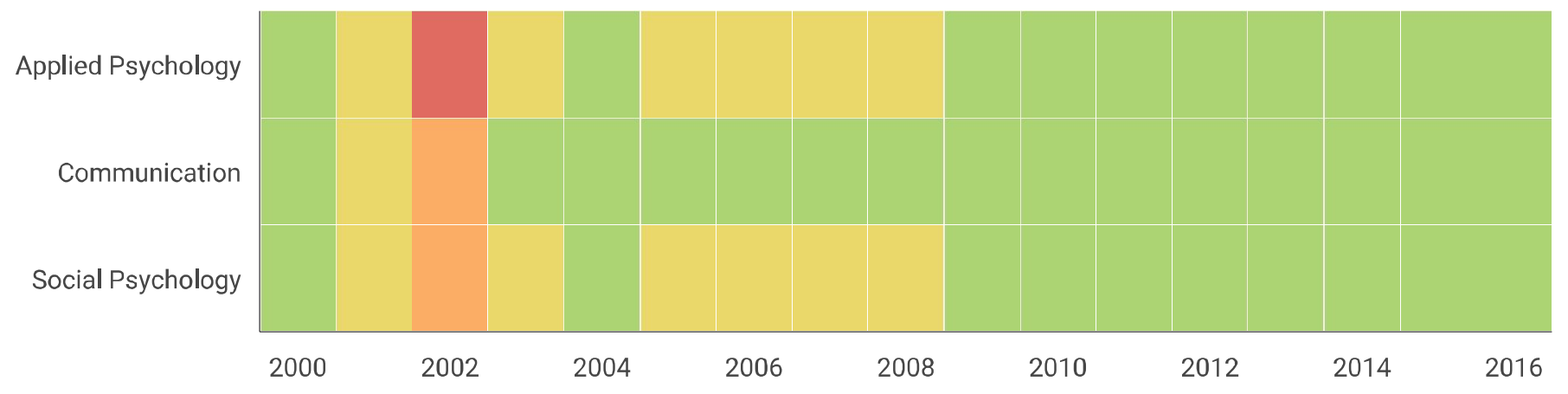

SJR 

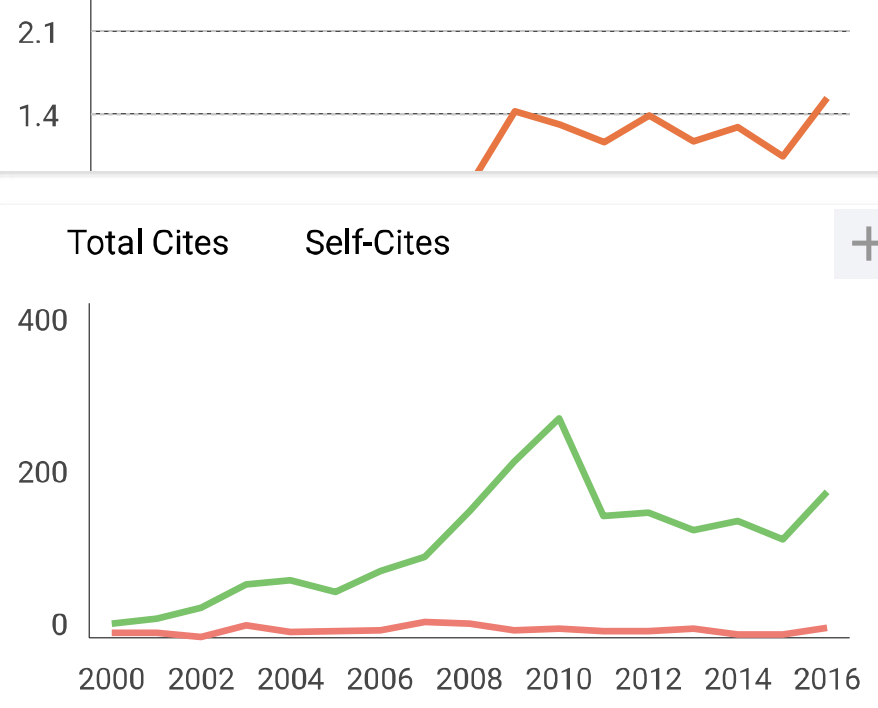

External Cites per Doc Cites per Doc

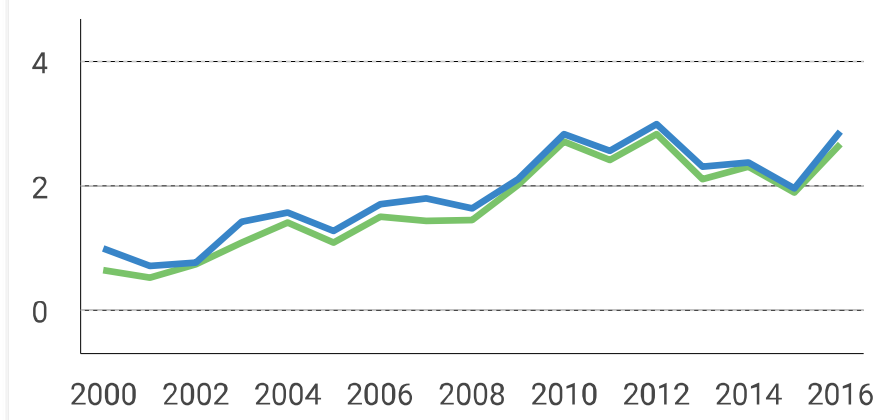

Citable documents Non-citable documents $\quad+$

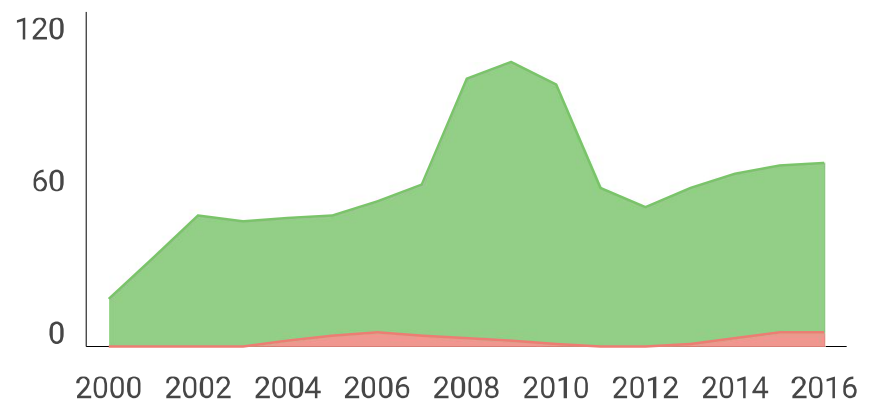

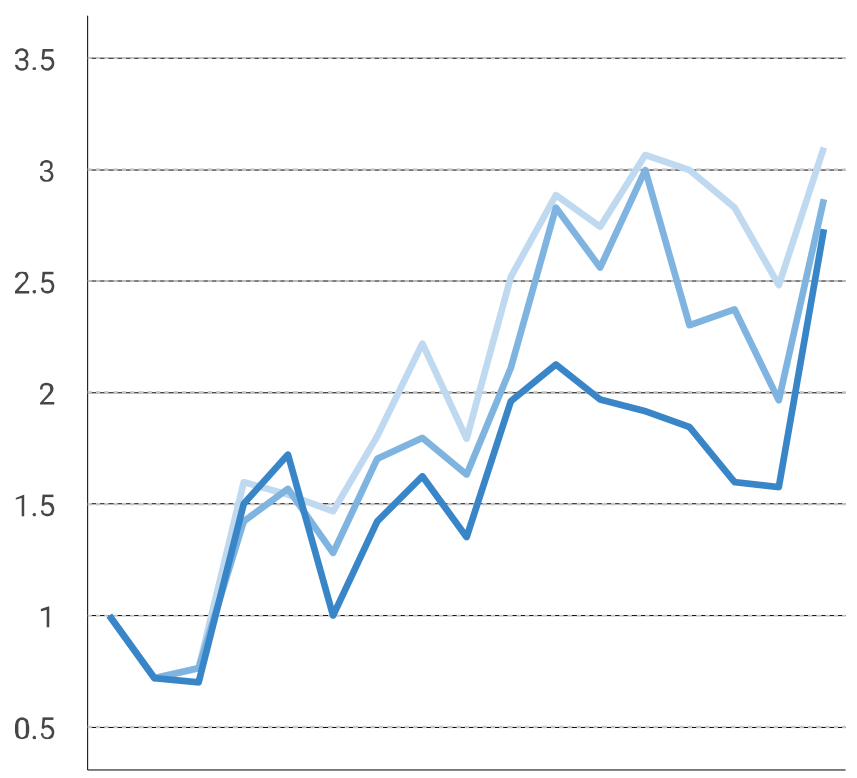

$\%$ International Collaboration

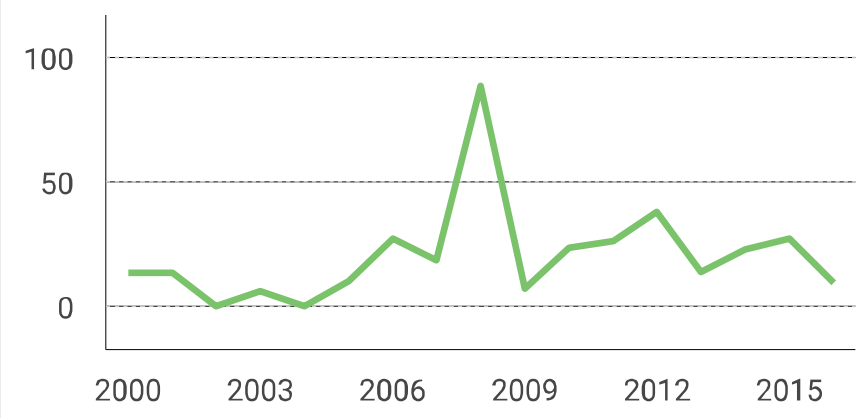

Cited documents Uncited documents

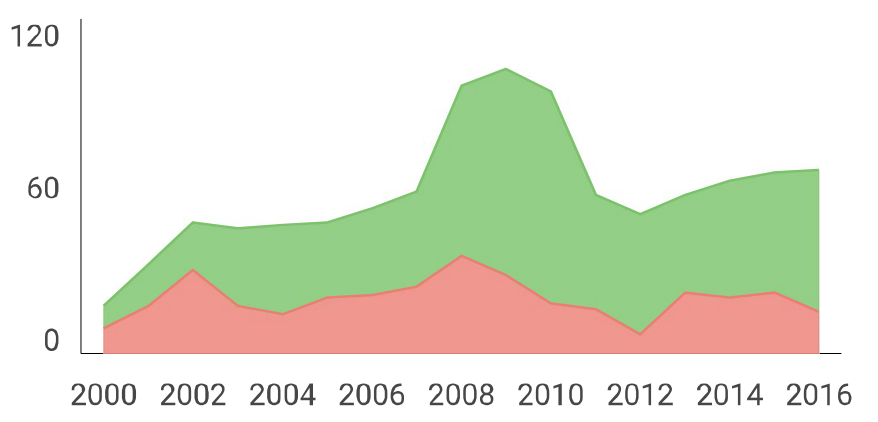




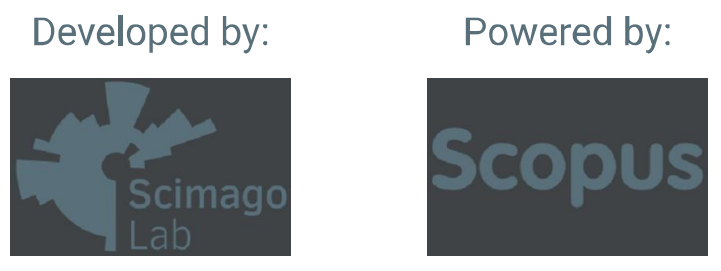

Follow us on Twitter

Scimago Lab, Copyright 2007-2017. Data Source: Scopus ${ }^{\circledR}$

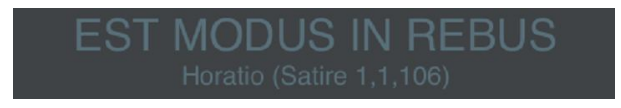

